\title{
The role of Civil Society Organisations in post-conflict development of northern Uganda
}

\author{
Denis Musinguzi ${ }^{1}{ }^{*}$
}

(C) Uganda Martyrs University

\begin{abstract}
This article examines the role of Civil Society Organisations (CSOs) in post-conflict reconstruction and development of northern Uganda. The analysis is informed by the increased spate of violent conflicts in Africa since the end of the Cold War; the destruction caused by violent conflicts; and the significant role played by CSOs in post-conflict reconstruction and development. The northern part of Uganda witnessed the most protracted and devastating Lord's Resistance Army (LRA) conflict in the country's post-independence history, which forms the central focus of the study. To generate a deeper analysis of the role of CSOs, this article delves into the historical evolution of civil society from the classical thought of ancient Greece to the modern and contemporary perspectives of civil society. The analysis of the role of CSOs in post-conflict reconstruction and development is framed in the war-topeace transition; and recognises the dialectical relationship between peace and development. The article examines the community's perceptions on the role of CSOs and its responsiveness to community needs. It concludes with a reflection on simmering issues, which if not properly addressed, could destroy the positive inroads and peace dividends being realised in northern Uganda. A constructivist and qualitative methodology guided the study, which sought to interpret reality from the context of the respondents.
\end{abstract}

Key words $\cdot$ Civil society $\cdot$ Conflict $\cdot$ Post-conflict reconstruction $\cdot$ Peace and development

\section{Introduction}

The world has witnessed unprecedented increase in the spate of violent conflicts since the end of the Cold War. Most of these conflicts have remarkably presented a shift from inter-state to intra-state conflicts (Philpott, 2010). In a much disquieting manner, Africa has remained a theatre of intra-state armed conflicts that continue to devastate different parts of the continent. Northern Uganda, in particular, suffered for more than two decades the most protracted and devastating conflict in the country's postindependence history, which eventually spread to parts of the Democratic Republic of Congo (DRC), South Sudan, and Central African Republic (CAR). The unfolding tragedy of the Lord's Resistance Army (LRA), led by Joseph Kony, witnessed widespread mass atrocities and repression in which people were killed, abducted and maimed, while others were displaced and condemned to live miserable life in

\footnotetext{
${ }^{1}$ Uganda Martyrs University,*dmusinguzi@umu.ac.ug
} 
Internally Displaced People's Camps (IDPCs). The rebellion disrupted social life; led to physical, political and economic destruction; caused unspeakable psychological trauma; and meted untold pain and suffering on the communities of northern Uganda. Due to their vulnerability, children and youths were caught up in violence, suffered and caused suffering, including recurrent rape, torture and indiscriminate killings. In their fight against the government, the LRA rebels abducted hundreds of minors into their fighting ranks, eventually alienating them from the local population (Angucia, 2010).

Despite its ruinous nature and effects, the northern Uganda conflict was least understood, regularly misconceived and wrongly portrayed, and often simply ignored (Omach, 2011). Different actors, both governmental and non-governmental, misinterpreted the concerns of northern Uganda at various moments during the course of the conflict, which complicated the attainment of a peaceful settlement. From the outset of this armed conflict, many voices deep-down the local tier remained utterly silent at the expense of competitive hegemonic discourses; and for a considerable time, the government of Uganda denied any alarming scale of the shattering caused by LRA rebel activities (Gingyera-Pinycwa, 1992). More so, the international community for the most part of the conflict simply echoed the applauses of Ugandan government for cosmetic democracy and economic recovery, while at the national level, most Ugandans variously referred to the conflict as 'a northern Uganda problem,' or merely 'an Acholi affair' (Oryem, 2004: 5).

Given the destruction of the war, northern Uganda lagged behind the rest of the country in all the key socio-economic indicators, with $61 \%$ of the people living in poverty. This percentage was almost twice as much the national $31 \%$ poverty prevalence rate (UBOS, 2006). To ameliorate the intense suffering that it caused, the conflict attracted the proliferation of local and international Civil Society Organisations (CSOs), including in the context of this analysis, local and international Non-Governmental Organisations (NGOs), faith-based organisations, and Community-Based Organisations (CBOs).

During wartime in northern Uganda, CSOs were engaged in humanitarian relief, peacebuilding, and promotion of human rights. However, the aid work and development assistance offered by CSOs during the time of war was crisis-driven and,

could not reach beyond the immediate limitations of the insecurity imposed by the LRA. As such, relief, donations, grants, projects and alleviation plans tended to revolve around the immediate existential threats that limited the quality of life of the population in IDPCS (Bigirimana, 2015: 9).

Since the conditions of war could not allow an enabling atmosphere for collective action, both government and CSOs could not follow a unified intervention plan. Consequently, "most relief efforts addressed crises without seeking to build an underlying infrastructural base for recovery" (ibid: 9). Since no one was sure when the 
war would end, CSOs found it prudent to invest resources to meet only those needs that were urgent and humanitarian in nature. Unfortunately, as an unintended consequence, "disjointed and random relief coincidentally disempowered the population in northern Uganda and entrenched a mindset of dependence on handouts" (Bigirimana, 2015:11-12).

The end of military hostility in 2006 inevitably breathed in a lot of relief to the communities, and as a result witnessed a change in focus by CSOs to post-conflict reconstruction and recovery. The post-war stability enabled these organisations to work in collaboration with government to envision and pursue sustainable peace and development in northern Uganda. While remarkable success has been realised in the key milestones of humanitarian assistance and short-term relief to prevent death and human suffering, facilitation of development or long-term efforts to improve quality of life, the overall contribution of CSOs has largely remained ambivalent. ${ }^{2}$ On the one hand, most CSOs have struggled to make their contribution manifest to the civilian population, notwithstanding their good intention. On the other hand, despite their various contributions to the well-being of post-war communities, some CSOs have been perceived as predatory moneymaking schemes that prey on the suffering communities that they are supposed to care for. ${ }^{3}$

Against this backdrop, this article examines the role of CSOs, their level of responsiveness to the needs of the community, and the extent to which they are appreciated by their intended beneficiaries. The role of CSOs is studied in the framework of transition from crisis-driven development during wartime to reconstruction and sustainable development of post-conflict northern Uganda. CSOs are treated as key actors that complement various efforts of the state, especially in reaching out to the most vulnerable communities where state presence is minimal or non-existent.

This article is divided into five sections. The first section presents the methodology of the study, detailing the different phases of research, study designs and datasets used, as well as methods of data collection and analysis. The constructivist and qualitative nature of this study, which seeks to interpret reality from the context of the respondents, is underscored. The second section introduces the historical evolution of civil society, right from the classical thought of ancient Greece, through the medieval period of Christian thinkers to the contemporary perspectives of civil society. The evolution of civil society is analysed in the context of the increasing scrutiny of the

\footnotetext{
${ }^{2}$ The dominant view that emerged especially from key informant interviews with community opinion leaders is that while non-state actors were generally driven with good intentions, their ability to make significant contribution within the community was always very limited. The extent of their contribution in both war and post-war period was also limited to particular communities, leaving others in the agony of depravity.

${ }^{3}$ While the ability of majority state actors was limited by the intensity of the challenge they confronted and financial constraints, some non-state actors were perceived by the community as predatory actors who were driven by personal gains and used their organisations, both real and briefcase organisations, only to prey on the suffering of the communities.
} 
historical perception about state's capacity to reach all society, and the emergence of CSOs as interested partners that complement state activities and actively participate in human progress.

The third section discusses the theoretical framework and highlights the key analytical lenses that guided the discussion of the findings. Given the study's focus on the shift from war to post-conflict scenario, the theoretical framework focuses on the roles of non-state actors and establishes a close connection between peace and development. The framework recognises the dialectical relationship between peace and development; but given the war-to-peace transition context that informed the study, peace is looked at more as a precondition for development.

The presentation and analysis of the role played by CSOs, community perception of their responsiveness to community needs and the extent to which they are appreciated by their intended beneficiaries constitutes the fourth section, which is the main component of the article. However, this is not a comprehensive analysis of the various interventions by CSOs, but an exposition into their role in managing the transition from conflict to peace and sustainable development. The final section is the conclusion and recommendations. It reflects on simmering issues, which if not properly addressed, could destroy the positive inroads and peace dividends being realised in northern Uganda.

\section{Methodology}

Anchored in a constructivist paradigm, the work presented in this article was informed by and is based on two phases of research. The desire to study the role of CSOs in the post-conflict development of northern Uganda was initially informed by my doctoral research, which was conducted in 2011 and 2012. Entitled, From Ominous Hostility to Restored Relationships: Transforming Northern Uganda Conflict Using Lederach's Integrated Framework for Peacebuilding, the doctoral thesis interrogated how different levels of stakeholders interact to generate synergy for sustainable peace. During the study, various voices echoed the essentiality of peace and development and the vital role played by CSOs. Since these organisations had made sufficient inroads in the field of peace and development in northern Uganda, the need to examine their role could not have been more urgent.

Indeed, the second phase of research was conducted to specifically interrogate the role of CSOs in peacebuilding and development of northern Uganda. The research was conducted using a case-study design with specific selection of Gulu and Kitgum districts in Acholi sub-region and Lira district in Lango sub-region. Since the structuring of development response for northern Uganda includes various parts of the country that were affected by the conflict such as West-Nile sub-region and Northeastern sub-region, the case study design was intended to cover Acholi and Lango subregions which formed the epicentre of the LRA rebellion (Angucia, 2010). 
The population of research comprised selected CSOs operating in the studied districts, and community-based opinion leaders who would provide the community perspective. Limited funds did not allow research within the communities for further interaction with specific beneficiaries; however, the rich sharing from the opinion leaders sufficed. The research used purposive sampling technique to capture the essential data needed for deeper analysis. To ensure some level of methodological rigor and integrity, the study relied on both primary and secondary sources of data. The primary data was collected using in-depth interviews and structured questionnaires. The structured questionnaires were used to collect information from representatives of the studied civil organisations, while the opinion leaders were reached using in-depth interviews. In-depth responses generated through interviews were able to corroborate the views of civil society representatives generated through questionnaires. Because the study is largely qualitative, sampling did not take into account the numerical strength of respondents but prospects of in-depth data. Subsequent interactions with some of the key respondents revealed more and nuanced positions as reported in the section on the study findings.

Content analysis based on review of secondary sources and narrative analysis based on primary responses was used for data analysis and triangulation of both data sources. Content analysis allowed making inferences and analytical comparison of the content of communication across war and post-war settings, while narrative analysis helped to capture the voices of the respondents and fill gaps in the literature. The method was useful in the understanding of sociological questions about groups, communities, and contexts through the individual's lived experience (Bryman, 2008). Besides, the tellers of the narratives, as Druckman (2005) points out, are the experts of their own stories. Their responses augured well with the constructivist perspectives of how they understand and interpret their own reality. This allowed for broad and thematic understanding of the role of CSOs and the extent to which the role is appreciated by the beneficiaries and other stakeholders.

\section{Evolution of civil society}

The concept 'civil society organisations' is employed in this study to include,

A sphere of voluntary action that is distinct from the state, political, private and economic spheres, keeping in mind that in practice the boundaries between these sectors are often complex and blurred. It consists of a large and diverse set of voluntary organisations--competing with each other and oriented to specific interests--that are not purely driven by private or economic interests, are autonomously organised, and interact in the public sphere. Thus, civil society is independent from the state and the political sphere, but it is oriented towards and interacts closely with them. (Paffenholtz, 2010:3) 
Civil society has had a long history but has undergone a renaissance in recent years. According to Ehrenberg (1999: xi), "the origins of civil society can be found in a classical heritage that understood it as a politically organised commonwealth." It is clear in Ehrenberg's observation that civil society was originally synonymous with political society. This view is also held by Frederick Starr, who contends that civil society was until recently understood in the realm of political philosophy as:

a state or condition that exists when a people is ruled by law, when freedom of speech and association prevail, when a multitude of voluntary groups work freely to foster civic ends, and when the people consider themselves to be citizens rather than subjects (Starr, 1999: 27).

However, the common modern meaning of civil society has transited to emphasise autonomy from the state. The understanding of civil society as being synonymous with political society was born with the concept of civil society in ancient Greece where it originated in the works of thinkers, notably Plato, Aristotle, and Cicero. As noted by Ehrenberg (1999), Plato emphasised unity and held that civil society can never be built on individual interest. To Plato, only the state, led by people who do not have personal desires, can guarantee happiness, justice and civilised life. Aristotle, on the other hand, saw the civil society as a hierarchy of associations, wherein the role of the family and the village would support the needs of the life itself and the promotion of good life. Unlike Plato, Aristotle saw the importance of heterogeneity, and argued that the core of civil society lies in the middle class since it is the middle class that can mediate between and combine rich and poor and hence guarantee stability (Ehrenberg, 1999). Cicero agreed with Plato and Aristotle that the requirement for civilised life was stability.

Without deviating from the notion of civil society as the realm of political society, the concept of good life played a central role in the definitions of the civil society in the medieval period. Augustine contended that the state was needed to maintain peace, while Thomas Aquinas re-echoed the Aristotelian principle of association and viewed civil society as a natural part of human life, with political order as the highest form of human association (ibid). Unlike in ancient Greece where the final source of authority was secular, in the medieval period secular notions of political life succumbed to Christian theories of civil society and the final source of authority was religious (Cohen and Arato, 1994). Despite the source of its final authority, civil society made civilisation possible since people lived in associations that were governed by law and protected by powers of a higher authority.

The conception of civil society as a synonym to political society remained eminent even in the modern conception of civil society. The conception is reflected in the two modern strands represented on the one hand by the liberal conceptions of Niccolo Machiavelli, Thomas Hobbes, John Locke, Adam Ferguson, and Adam Smith, which underscored individual interests, private property, market economy, political 
democracy and the rule of law. On the other, it is reflected in the works of JeanJacques Rousseau, Baron de Montesquieu and Edmond Burke, who emphasised notions of community and intermediate organisations or civil society, whose solidarity reconciled the subjectivity of individual interests with the objectivity of the common good (Ehrenberg, 1999).

Underscoring the centrality of stability and leadership, both Machiavelli and Hobbes saw the civil society as a sphere where public and individual interests are mediated. Machiavelli recognised Rome's tradition of civic republicanism and proposed strong secular leadership as formidable authority that would turn conflict into stability. Viewing civil society as an artificial creation for purposes of survival, Hobbes theorised politically organised universal community and underscored constitutive sovereign power that alone would guarantee peace and stability (Ehrenberg, 1999). It is imperative to note that the understanding of civil society by Machiavelli and Hobbes departed from the medieval emphasis on the church to the classical theories of Plato and Aristotle that emphasised the centrality of the state (Starr, 1999).

The old Aristotelian and the medieval understanding of civil society as the realm of political life was modified under liberalism, where civil society meant the society of the free citizens. Like Aristotle, prominent liberal thinkers such as Immanuel Kant, John Locke, Adam Smith, Adam Ferguson and John Stuart Mill saw civil society as equivalent to civilisation (Kumar, 1994). The liberal thinkers were grappling with the question of what constitutes the core of civil society. While Kant regarded civil society as a protected sphere that allowed people freedom to make their own decisions, for Locke and Smith the core of civil society was based on individual property and thus their civil society was the market. The state was a protective organ of the civil society. Afraid of the disrupting elements of the market, Ferguson departed from Locke and Smith and depicted the civil society as a mode of human existence that was grounded on moral sentiments, which build bridges between self-interests and moral welfare of the community (Ehrenberg, 1999).

During the Enlightenment period, Jean-Jacques Rousseau drew from Ferguson and emphasised natural sentiment accompanied with love to oneself as the basis of civilisation. For Rousseau, the need for security draws isolated people together and civilises them. Baron de Montesquieu defended the status of the aristocracy and developed the theory of mediating organisations. Drawing from the Aristotelian notion of three classes in society, Montesquieu viewed civil society as intermediate organisations between the institution of the family and the state; and argued that legal institutions should protect civil society. It is instructive to recall Ehrenberg's (1999: 148) observation that "it was Montesquieu who first placed intermediate organisations at the centre of civil society."

The German Philosopher, Wilhelm Friedrich Hegel in the early 19th century introduced a quite different perspective (Ehrenberg, 1999; Starr, 1999). Premising his theory on three spheres of social life: family, civil society and the state, Hegel broke 
the equation of civil society and emphasised the need for social and civic institutions to regulate the individual interest. Furthering Montesquieu's idea of intermediate organisations, Hegel depicted civil society as a network of social relations standing between the family and the state, linking self-serving individuals to one another in a mediating sphere of social connections and moral freedom (Ehrenberg, 1999). Drawing it closer to its current nature, Hegel provided an overarching understanding of civil society as not the entire body politic, but only that part of society that organises itself voluntarily to promote the common good. Civil society is understood and treated in this article in this context.

The contemporary discussion of civil society arose from the turbulence of East Europe in the late 1970s, especially in Poland where the Solidarity movement used the concept in opposition against the totalitarian states. The revolution in thinking about civil society was precipitated by improved education levels, impressive strides in communication, and contacts with other communities, where civil society was understood as emerging new powerful movements for change. Consistent with the rise of neo-liberal political economy of the Third World, CSOs were looked at as a critical force in the management of political and socio-economic agenda in these countries. Given that neo-liberal perspectives conceive most of Third World states as failed states and markets as imperfect, CSOs were increasingly seen and projected themselves as viable alternatives in complementing state efforts and providing services needed by the poor people (Dicklitch, 1998: 2).

Cohen and Arato (1994) distinguished civil society from political and economical fields of action; and explained the composition of civil society to include plurality, publicity, privacy and legality. According to them, plurality refers to "families, informal groups, and voluntary associations whose plurality and autonomy allow for a variety of forms of life." Publicity relates with "institutions of culture and communications," privacy means "a domain of individual self-development and moral choice," while legality relates to "structures of general laws and basic rights needed to demarcate plurality, privacy, and publicity from at least the state and, tangentially, the economy" (Cohen and Arato, 1994: 346).

This study draws on Paffenholtz's (2010) definition of civil society, which provides civil society as distinct from but oriented towards and working closely with the state. The contemporary usage also connotes on the one hand a political sphere where independent citizens can arrange their government and, on the other, the sphere outside the realm of the state (Cohen and Arato, 1994). This study treats civil society in this very context as distinct from but interacting and working closely with the state. In common parlance, civil society bridges the gap between individuals and state; and complements state's effort in the provision of services to the most vulnerable communities where the state presence is minimal or non-existent.

It is apt to note that the role of CSOs is all the more important among the conflictridden communities, where the state is often absent in most parts, as was the case in northern Uganda during the LRA insurgency. As confirmed by Bigirimana (2015: 38), 
during war, "the Government was 'over its head' working tooth and nail to maintain security and protect the lives of the innocent whilst, at the same time, carrying out offensive military operations to get rid of Kony's forces."

As such, "in the first years of the rebellion, the bulk of relief work and humanitarian assistance was rendered by Non-Governmental entities" (ibid). Given their centrality, it was necessary to assess the role played by CSOs in post-conflict development of northern Uganda.

\section{Integrated approach to post-conflict development}

The discussion of the role of CSOs in the post-conflict development of northern Uganda in this article is understood in the context of the evolution of civil society as key actors in peacebuilding and post-conflict development. The study argues for the strong link between peace and development. Given the war-to-peace transition context in which the analysis of this study is framed, peace is a looked at as a necessary condition for development; and peacebuilding ultimately entails concerns for development. Consistent with this conceptualisation, the actors and approaches model under the integrated framework for peacebuilding, advanced by Lederach (1997), has been used as the theoretical framework for guiding the analysis of the role of CSOs. The model situates the analysis within a conflict and post-sensitive environment; therefore, provides a firm basis upon which a strategy for effective and sustainable peace and development process can be anchored.

The choice of the integrated approach is informed by Culbertson's (2010:78) contention that in creating peacebuilding and development frameworks, those developing an intervention strategy must consider whether to emphasise prioritisation or integration. Integration is preferred since it addresses the limitations of prioritisation approach, typified by the traditional statist diplomacy and the liberal peace economics of "development as usual" approach. As such, the integrated approach, drawing on sensitivity to local conditions and the contribution of local resources, provides for and holds greater potential for guiding the analysis of the role of CSOs as key actors in conflict and post-conflict development.

The integrated framework draws its justification from the need to transcend the crisis management approach under the international statist diplomacy, which has dominated conflict resolution and peacebuilding trajectory, and its failure to effectively resolve conflicts or achieve sustainable post-conflict peace and development. For Lederach (1997), the crisis management approach is limited by lack of long-term view of the situation, a myopic focus on crisis negotiation, and the failure to appreciate the multiplicity and interdependence of peace building roles and activities in conflict resolution and post-conflict reconstruction. This study's focus on the transition from crisis-driven to sustainable development, focusing on the role of CSOs within the interactive cooperation with government, is informed by this strategic peacebuilding and post-conflict reconstruction and development mind set. 
The integrated framework highlights four key themes, namely long-term as opposed to crisis approach to conflict resolution and development; the importance of considering and integrating the roles and approaches by different actors, in this context the integration of the roles of CSOs within the government framework of Peace, Recovery and Development Plan (PRDP). It also highlights consideration of specific timeframes for guiding peace building and development activity; and transformation of conflict relationships into peace relationships. The analysis in this article employs the first two themes, namely long-term as opposed to crisis approach to conflict resolution and development, and the importance of considering and integrating the roles and approaches by different actors, focusing on CSOs given their increasing role in complementing state efforts in the provision of services to vulnerable communities. The actors and approaches model is used for this study basing on the informed conviction that successful peacebuilding and development in northern Uganda must consider the affected population, and how to empower the local population to own and direct the process for sustainable peace and development.

The integrated framework classifies actors under three levels of leadership: toplevel leadership, mid-range leadership, and grassroots leadership (Lederach, 1997). Top-level leadership is comprised of very few but highly visible actors, mainly from government (including the military), high-level CSOs and international actors. Their focus is on high-level negotiation and amelioration of the suffering caused by war; and a highly visible mediator normally leads them. The middle-range actors consist of leaders in respected sectors such as ethnic and religious, civil society and academia, who all enjoy substantive ties between top-level leadership and grassroots leadership. These normally use problem-solving approaches, training in conflict resolution and survival skills, and insider partial teams in peacebuilding and attainment of livelihood needs. Middle-level leadership functions within the conflict setting; hence, directly represent the interests of affected communities more profoundly than the top-level leadership. The grassroots leadership include massive numbers of people or communities within the conflict area, who often bear the full brunt of the conflict. The leadership at the grassroots level includes local leaders, indigenous NGOs, community developers, local health officials, and camp leaders. Their approaches include local peace commission, grassroots mobilisation and training, psychosocial work in postwar trauma, and development initiatives. While the conflict is a central cause of their suffering, people at this level are in a survival mode, in which meeting the basic human needs of food, shelter and safety is the daily struggle. As such, actors at this level are more inclined to survival needs during war and livelihood needs in postconflict setting to which development is most oriented. It is instructive to note that CSOs play a crucial role at all levels of leadership, hence a very instrumental force in post-conflict development. The actors and approaches model is, therefore, relevant and suitable for assessing the role of CSOs in post-conflict development of northern Uganda. 
Actors considered in the analysis are the CSOs and state actors, who provide relief and development work as well as the community of beneficiaries, represented by community opinion leaders. The choice of actors and approaches model is consistent with the logic of peace and development underscored by the United Nations Educational, Scientific and Cultural Organisation (UNESCO). It posits that since it is the minds of men and women that wars and conflicts are initiated, it is in the minds of men and women that defences of peace and the conditions for sustainable development must be built. It was, therefore, pertinent to interrogate how concerns for peace and development in post-conflict northern Uganda are framed in the mind of and pursued by CSOs.

Approaches refer to party actions, including a full-range of all measures and mechanisms taken with a purpose of contributing to post-conflict peace and development. In this analysis, interventions of CSOs in northern Uganda have tended towards four milestones: humanitarian action, relating to short-term relief to prevent death; development, pertaining to long-term efforts to improve quality of life; human rights, entailing efforts to create supportive political environment; and peace-building, signifying programmes specifically tailored to address conflict. With specific focus on the role of CSOs in the promotion of development manifestly in their long-term efforts to improve quality of life, assessment of the interventions of the actors is, therefore, essential to this analysis.

It should be underscored that in times of armed rebellion, the role and approach of CSOs was both defined and constrained by the circumstances of war. As highlighted by Bigirimana,

Because of the crisis nature of the situation in Northern Uganda, agencies
who intervened [in times of war] in the sectors of health and sanitation,
water, education and food aid, implemented their projects according to
their capacity and the need at hand. There was no overarching framework
through which their activities were directed in order to achieve a uniform
set of results across the region. By so doing, only the symptoms of the
problem and not the roots could be addressed.... In essence, interventions
were only relevant to the temporary needs of the community. To the level
that they ameliorated suffering and enabled coping with stress of war,
they were not turned to upholding lasting development (2015: 38-39).

The transition from the atmosphere of war to that of stability demanded change in thinking and approach of actors from mere focus on humanitarian relief to enabling post-conflict reconstruction, recovery and development. Bigirimana ably captures the initial transition in thinking and response of actors,

By the 2000s, the LRA strength was significantly reduced. At this point, viability of social development made sense. For the very first time, the Government of Uganda and the World Bank drew up a wide-reaching 
initiative to build the capacity of Northern Uganda (Bigirimana, 2015: 40).

While this initiative resulted in the launch of the Northern Uganda Social Action Fund (NUSAF I) in February 2003, a more comprehensive and overarching framework for recovery and development was realised later with the launching of the Peace, Recovery and Development Plan (PRDP) for northern Uganda in 2009. PRDP was essentially intended "to direct the mainstreaming of interventions in northern Uganda in a more coordinated manner to avoid the duplication and overlap that had characterised past initiatives" (Bigirimana, 2015: 51).

This means that the focus and approach of civil society actors were expected to follow and be guided by the dictates of the PRDP framework.

The use of actors and approaches model was, therefore, constructive in generating clear understanding of the role of CSOs in post-conflict development of northern Uganda. Given its focus on actors and sensitivity to conflict and post-conflict environment, the framework provides useful analytical parameters for analysing the role of CSOs in the post-conflict development by chronicling the transition from crisis-driven development of wartime to more social and sustainable development initiatives in the post-conflict northern Uganda. This adds analytical value to the analysis and offers useful lessons for sustainable peace in northern Uganda.

\section{Actors in conflict and post-conflict development}

This section presents and analyses the role of CSOs in post-conflict development of northern Uganda, taking cognisance of the transition from crisis-driven development precipitated by times of turmoil to reconstruction and development in post-conflict environment. The section delves into the approach by CSOs; the closeness of the participating organisations to their intended beneficiaries; and the community perceptions of the role played by CSOs in post-conflict development of northern Uganda. The section underscores the extent to which different parties to the conflict appreciated them.

The northern Uganda conflict attracted a wide-range of actors, representing all the levels of leadership as indicated in the integrated framework for peacebuilding. During war, different CSOs pursued peace advocacy campaigns to bring to an end to hostilities as mediators and facilitators of the peace process, and provided relief services to the communities especially those in IDPCs. They included United Nations High Commissioner for Refugees (UNHCR), United Nations Human Rights (UNHR), the Norwegian Government-funded Acholi Religious Leaders Peace Initiative (ARLPI) and the Justice and Reconciliation Project (JRP), the United States Agency for International Development (USAID)-funded project of Northern Uganda Transition Initiative (NUTI), and International Rescue Committee (IRC). These have continued to operate in post-war northern Uganda, supporting interventions in 
psychosocial support and capacity building programmes for development. Their focus is on the victims of hostilities such as youths, violated women and girls, landless Internally Displaced Person (IDP) returnees, and former abductees.

Other CSOs pursued humanitarian interventions in a bid to alleviate human suffering and created livelihood opportunities. These included the Norwegian Refugee Council (NRC); United Kingdom's Department for International Development (DFID)-funded project of CARITAS and Voluntary Services Overseas (VSO); Oxfam; War Child (Canada and Holland); World Vision; Justice and Reconciliation Programme (JRP); Action Against Hunger; Community Integrated Development (CID); and Refugee Law Project (RLP). They continue to provide humanitarian relief and provide support for long-term development in post-war northern Uganda. Postwar community-based actors, notably the Community Integrated Development (CID), pursue peacebuilding activities and long-term livelihoods activities to facilitate postconflict recovery and development.

All the studied CSOs operate in northern Uganda, generally, and the two selected sub-regions in particular. However, variations exist with the extent of the number of districts covered. Some of the organisations such as the Refugee Law Project operate beyond northern Uganda, extending to Central and South-western regions. Despite the collective usage of the term SOs, there is a noticeable distinction with regard to focus and mandate of different organisations.

The socio-economic and political context or the broader conflict environment legitimised the interventions by CSOs. In the first years of the rebellion, the bulk of relief work and humanitarian assistance was rendered by CSOs. As it carried out military operations to get rid of the LRA forces, the Government was preoccupied with maintaining security and protecting the lives of the innocent civilians. While the implementation of NUSAF I witnessed the transition from war to post-war stability, more effective and robust post-conflict development of northern Uganda was essentially kick-started with the launch of PRDP in 2009. The design, uniqueness and focus of PRDP is accurately captured by Bigirimana,

The PRDP design process took into account the unique situation of postwar northern Uganda. This kind of "special treatment" was meant to respond to the sensitive and immediate need to ensure stabilisation by establishing peace, enhancing security, resettling large groups of displaced persons and triggering economic activity. The larger agenda of bringing in economic development would not be achievable if these "preliminary" issues were not resolved (Bigirimana, 2015: 60).

PRDP offered a rich scope of intervention framework across which all stakeholders, including CSOs, were required to base their interventions. This was meant to create balance of deliverables between the urgent short-term community needs of the population and the long-term socio-economic outcomes desired for postconflict recovery and development of northern Uganda. Under the centralised-supply 
driven delivery, PRDP ensured the sharing of resources, information, strategy and approaches in delivering development assistance. As such, funding agencies and CSOs among other actors, submitted to the oversight and coordination by a local fund management unit whose work involved identifying priority areas for attention and the reviewing and approval of implemented development projects (Republic of Uganda, 2012).

The philosophy of PRDP was to promote socio-economic development of the communities of northern Uganda, and bridge the gap between the North and the rest of the country so that the North achieves the "national average level" in the main socioeconomic indicators. Its cardinal aim was to improve coordination of the reconstruction efforts taking place in northern Uganda; and included a monitoring function of the activities taking place in accordance with their respective programmes (ibid). PRDP's ability to bring together and coordinate development efforts by different stakeholders is aptly summarised by Bigirimana,

To accommodate and recognise the value and long-standing good will of the Development Partner and Non-Government Organisation community, the Stakeholder Forum was created. This forum fostered a cordial space in which joint monitoring discourses on PRDP were augmented by discussions between local and international players. The exchange eliminated suspicion, tendencies of unilateral action and reinforced the problem-solving structure of the forum (2015: 89).

International agencies such as the USAID and DFID have worked through budget and off budget to CSOs to promote prospects for development, stability, and prosperity of the region. In addition to supporting and advancing peace and stability within Uganda, USAID/Uganda has significantly contributed to the return of peace, recovery and development to northern Uganda. With recommendations of a 2010interagency conflict assessment, USAID's programming focuses on conflict prevention, conflict-management capacity building and promotion of reconciliation in northern Uganda. USAID-supported programmes have particularly worked to facilitate access to justice in resolving land disputes, promotion of reconciliation and provision of opportunities for people to develop collaborative solutions. USAID also supports targeted local government structures; community based organisations and traditional institutions to prevent, and manage conflict over land, water and, promote reconciliation USAID Fact Sheet, (2014). The Norwegian Government-funded ARLPI, a local initiative that has operated in northern Uganda since turbulent times, has also vigorously worked to resolve land conflicts incessant in the region. ${ }^{4}$

DFID has worked with national and local government, and CSOs to improve the quality of health, education and livelihoods services that are inclusive, accessible, and accountable to disadvantaged and vulnerable groups. DFID provided funds for the

${ }^{4}$ Interview with an opinion leader, Kitgum, March 28, 2013 
Youth Development Programme and The Private Sector Grants Scheme through the Northern Uganda Youth Development Centre. As noted by Bigirimana,

The Youth Development Programme started in 2010 with a target funding of GBP 12 million. It was a skills-centred initiative that sought to foster a better future for the youth in northern Uganda. The main route for achieving this was literacy, vocational skills and apprenticeship. The usefulness of this initiative revolved around its focus on youth who had not completed primary school (2015: 109).

The Youth Development Programme built a network of providers who offered training in vocational and life skills. DFID channelled its funding through VSO to facilitate the training. Furtherance to the first aspect of its overall programme goal of supporting post-conflict recovery and development in northern Uganda, in particular the districts of Gulu, Lira and Kitgum (which constituted the scope of our study). It was revealed during an Interview with a VSO official (Gulu, July 9, 2015) that VSO works with other CSOs to develop communities, promote social inclusion of disadvantaged members of the communities and advocate their rights. Under the Youth Employment and Local Governance project, VSO has generously worked to improve socio-economic opportunities for youth in northern Uganda by increasing opportunities for employment and strengthening the capacity of local leaders to represent disadvantaged people, especially youths.

It was instructive to establish that Daniel Comboni Vocational Training Institute (DCVTI) under VSO, Uganda, has supported 45 enterprises. The trained youth are supported with start-up capital to establish joint businesses comprising ten members. Tracer studies are conducted to identify established youth groups who are then supported with the start-up capital to the tune of UGX 3 million (equivalent of \$850), which is given to the members to strengthen their business. The youth were trained under VSO's Youth Development Programme, with funding from UK's DfID. According to VSO's Uganda Strategy (2012), VSO's implementing partners include Most At Risk Populations (NGO network), Forum for Education NGOs Uganda, National Forum for People Living with HIV/AIDS Network, National Youth Council, National Alliance for Volunteering Efforts, Uganda National Volunteer Link, African Network for Protection and Prevention of Children Against Neglect (ANPPCAN), Action For Development (ACFODE), Action for Cooperation in Research and Development (ACORD). In the OXFAM Evaluation Report (2014), it was established that OXFAM has posed a commendable impact on the livelihoods of the people in northern Uganda. This was achieved by funding a number of largely female genderempowering projects as well as grassroots-focused land rights campaigns through partner organisations, such as Uganda Land Alliance (ULA), ACORD, and Forum for African Women Educationalists (FAWE). The partner organisations reported that their capacity to influence policy formulation and implementation has greatly been boosted through OXFAM's funding and training to build their capacity in gender and land 
rights programming. In particular, OXFAM's influencing role in policy advocacy on gender justice and land rights has manifested fruition given its effective policy advocacy and good practices in the areas of gender and land rights.

In spite of the registered successes, challenges faced by partner CSOs in their engagement with OXFAM and those faced by OXFAM-funded CSOs still remain in their interface with beneficiaries. Key between these two sets of challenges were delayed disbursements of operational funds and stipends coupled with the tightly structured manner in which some interventions are designed and implemented, oftentimes devoid of local content accommodation. While deeply entrenched cultural mindsets are still an impediment to addressing some gender issues, especially women's access to land, some interventions are not yet owned by the community due to inadequate community involvement in their conception. This is detrimental to the sustainability of such interventions. Some of the recommendations given by the evaluation report, including preference for a more consultative approach in the design of OXFAM's interventions to be implemented by its on-the-ground partners; more discipline in sticking to timelines and disbursement of project support funds; strengthening strategic ties with cultural leaders to influence change of retrogressive cultural attitudes (OXFAM, 2014).

While all the participating CSOs operate within the studied districts, most are not headquartered therein. This raised concern of closeness to the beneficiaries, as well as the level of responsiveness of the interventions to the needs and interests of the intended beneficiaries. Indeed, $80 \%$ of the studied organisations are headquartered in Kampala, with a paltry $10 \%$ and $10 \%$ headquartered in Gulu and Lira, respectively. The disproportional remoteness from the areas of operation was justifiable given that most of these CSOs operated in northern Uganda during the turbulent periods of war, hence Kampala, Uganda's capital city, easily served as a safe haven for these organisations. However, the non-proximity of their national headquarters to their operational field more often than not made these actors to be detached from the onthe-ground realities of the civilian population under their care. This detachment favoured ill-informed and, sometimes, non-responsive interventions. In the end, these organisations relied more on third-party informants, co-opted or out-sourced members, on whose views they based their intervention plans.

In an interview (Kitgum, March 28, 2013), a prolific opinion leader noted with obvious frustration, and described the extent of lament for the non-proximity of CSOs to the realities of the conflict in northern Uganda,

These people [CSOs] who are headquartered in the safest neighbourhoods of Kampala have always had their network of people around here [Kitgum] who keep on feeding them with local news. Whenever they are aware of a piece of information about some tension taking place here, within no minute you see them come in, having driven their Land-cruisers [common field vehicles] all the way from Kampala to here. They quickly mobilise local people here within their reach and start on their community 
peace campaigns, and when evening comes, you see them packing their belongings and then cruise back to Kampala. One will ask, what kind of peace coming from far is this? How will we guarantee peace in such a rush because of the distance separating Kitgum from Kampala?

Unfortunately, detachment from the local reality attracts unresponsive interventions, rendering them fully or partially ineffective. The remoteness falls short of Woocher's (2011) instructive observation that successful policymaking and programming in conflict situations must start with an accurate understanding of local context, conflict actors, causes, and the dynamic relationships among them.

The operations of CSOs also manifested positive and negative correlations in terms of how they affected or were affected by the environment of instability. This was apparent in terms of the nature of relationship among the CSOs themselves, between CSOs and state actors, as well as between CSOs and the civilian population. The relationship between CSOs and state actors was more often suspicious of each other. Unfortunately, the relationships among CSOs remained for long neither integrated nor mutually reinforcing; no wonder most of their efforts did in many ways not matched intended expectations. While communities found solace from CSOs largely for lack of requisite support from government, lack of tangible impact on the ground has made some community members to view them as predatory moneymaking institutions at the expense of the suffering community. Besides, it was noted during interview with one of the opinion leaders that CSOs, especially those involved in humanitarian relief during war and short-term livelihood handouts in immediate post-war situation, responded to the symptoms rather than the causes of the conflict (Interview with an opinion leader, Gulu, March 30, 2013). This is consistent with Bigirimana's observation that in offering crisis-driven responses, "only the symptoms of the problem and not the roots could be addressed" (Bigirimana, 2015:39).

Concerns for justice as a necessary ingredient for peace and development were also registered. Some CSOs, notably the Refugee Law Project, work tirelessly to promote justice. Incidentally, the conflicting understandings of justice held by different postconflict communities threaten to disrupt the development dividends in post-conflict northern Uganda. For instance, the dominant narrative of international justice under International Criminal Court (ICC), which prefers punitive justice, is clearly at odds with the traditional justice system, which espouses restorative justice. While punitive justice seeks to punish the offender as a deterrent to future actions, restorative justice turns focus to the victim because it seeks to restore the aggrieved. Fortunately, both contemporary scholars and practitioners of transitional justice agree that local ownership is of paramount importance for justice mechanisms to be successfully adopted in a bid to create a peaceful post-war society.

In particular, the Acholi traditional justice system has earned prominent acclaim as a vital component to securing lasting peace and laying ground for sustainable development, mindful of numerous atrocities caused by war. Indeed, traditional and 
religious leaders emphatically argue for the many benefits of the Acholi traditional justice system as the best alternative means of criminal accountability for the past evil deeds by offenders. Presenting it as a strong foundation for post-conflict peace and development, the retired Anglican bishop of Kitgum and then Vice President of the ARLPI, Rt. Rev. Macleod Ochola II once noted,

Mato oput is one of the best justice systems in the world because it forgives, and restores broken relationships and creates the process of healing in the hearts of those who have been wounded by violence and death (Bartlet, 2009: 51)

In the areas of human rights promotion, child protection, and livelihood provision, most CSOs were initially driven by the humanitarian imperative owing to the vulnerability of many surviving victims of the war. Unfortunately, the extent of human rights violations and crimes suffered by children and youth has not been effectively addressed by transitional justice mechanisms. The main cause for this as captured by Aptel and Ladisch (2011) is that the interests and perspectives of the youth are often not sufficiently mainstreamed in the post-conflict development agenda, as is abundantly the case for northern Uganda. Global discourses on youth involvement in post-conflict development as highlighted by McEvoy-Levy (2011) indicate that practitioners have only recently begun to acknowledge the significance of young people's participation. The failure to mainstream youth needs, as instructively noted by Nobert Mao, ${ }^{5}$ is in part due to the relative disempowerment of the young people in general and the victimisation of children by the war in particular. This is compounded by lack of effective youth representation in numerous political entities and CSOs, notwithstanding the existence of international children and youth organisations such as UNICEF and Save the Children.

\section{Level of appreciation of specific interventions}

An attempt was made to ascertain the levels of appreciation of specific interventions of CSOs both during and after the war by other actors within the conflict sphere. The actors in peace building and post-conflict reconstruction and development included the Government of Uganda; the local community for whom interventions were made; and the staff of respective organisations as key implementers of the programmes and interventions. The key issues of concern were whether the implementing organisation's entire personnel or staff were fully qualified to carry out the

\footnotetext{
${ }^{5}$ Nobert Mao is a former two-term Member of Parliament (MP) for Gulu Municipality, former Gulu District Chairperson, former Presidential aspirant and currently the President of the opposition Democratic Party (DP). He offered an interview with the author on March 21, 2013, during the $3^{\text {rd }}$ Institute of African Transitional Justice (IATJ) organised by Refugee Law Project (RLP), Kitgum, Uganda.
} 
organisation's mandate in northern Uganda; whether the organisation's logistical and financial resources were sufficient to make an impact in northern Uganda; and whether each organisation's involvement in northern Uganda ensured the principle of impartiality and neutrality.

Interventions by CSOs during wartime, which were dictated by the circumstances of war and, as noted earlier, were largely crisis-driven. To the extent that these ameliorated human suffering and provided basic livelihoods, they were greatly appreciated by the other actors. It was quite revealing, however, that providers of humanitarian relief themselves had a low rating of humanitarian activity, appreciated merely as an existential necessity but rebuffed as a peace and development strategy. The open admission about the limited contribution of humanitarian relief to peace and development was compounded by the negative rating by some respondents of relief providers, who are seen to pursue more of personal as opposed to community interests. Limitations of humanitarian relief were exacerbated by the relationship of mistrust between the Government and CSOs, especially in the early years of the conflict, which did not allow a unified approach to service delivery.

The earliest attempt to build capacity was the initiative between the Government of Uganda and the World Bank, which culminated in the launch of NUSAF 1 (2003220). The International Development Agency (IDA), the leading funder of NUSAF I, contributed $96.35 \%$ of the total 224.83 billion Ugandan shillings that implemented NUSAF I interventions (Bigirimana, 2015: 42). Since the approach of NUSAF I was community-driven, the communities themselves generated the sub-projects that were undertaken. The key areas of intervention included education, water and sanitation, health, production and environment and community infrastructure. These were implemented under the four sub-components of Community Development Initiatives (CDIs); Vulnerable Groups Support (VGS), with a Youth Opportunities Programme (YOP); community reconciliation; and conflict management and institutional development. It was noted during interview with a youth leader (Northern Uganda Youth Development Centre, July 10, 2015) that while all the sub-components achieved considerable success, it is instructive to note that the youth sub-component saw the funding of 469 projects in the areas of carpentry, brick laying, tailoring, motor vehicle mechanics, hairdressing, metal fabrication and other mixed skills, which contributed to improving the livelihoods of the youth.

With regard to local support, a huge majority of key informants (3.9 mean score) agreed that their organisation's involvement during the turbulent times of conflict in the northern Uganda received warm welcome and support by the local people to whom their activities may have been dedicated. This claim was also corroborated during an earlier in-depth interview with an elderly opinion leader in Gulu (March 29, 2013)

The war between Kony's LRA and Museveni's [the president of the republic of Uganda] forces put us in a difficult situation. For many years as this armed conflict persisted, this situation was so miserable for us that 
we desperately depended on whatever goodwill that was available to ensure our survival. Those non-governmental organisations who took charge of alleviating our pain whilst in IDP camps, through education of our young ones, catering for special needs of our women, and assisting the elderly with their basic needs, were highly welcome here [Gulu] given that both Kony's and Museveni's camps remained insensible to our suffering for so long.

A good majority of key informants (3.7 mean score) agreed that their organisation's involvement during the turbulent times received warm welcome and support from existing stakeholders, both local and international. What emerged from the findings, however, is that different CSOs never harmonised or integrated their interventions to generate synergy requisite for effective and sustainable peace and development. CSOs continued to operate in isolation of one another, which made it all the more difficult for them to achieve credible singular impact, until when the PRDP was introduced to streamline development interventions in northern Uganda.

The guns finally fell silent in 2006 at the time NUSAF I was being implemented. The falling silent of the guns meant that development practitioners and social service providers could embark on a more comprehensive reconstruction and development agenda. As succinctly noted by Bigirimana,

The transition from an atmosphere of war, where humanitarian relief dominated intervention efforts, to one of reconstruction, demanded a change in thinking. This change was necessary among all the major players, that is, development partners, Government of Uganda policy makers, the Local Government, Non-Government and Civil Society Organisations and the beneficiary returnee population (2015: 71)

Since the national state is the starting place for any discussion in post-conflict reconstruction, "the state will necessarily play a central role in defining the contours of state policy, creating a new or reformed national identity and mythology, and allocating resources" (Roht-Arriaza, 2010: 232). Cognisant of its role, the Government of Uganda championed the PRDP as an overarching framework for reconstruction and development of northern Uganda. Education, health, water, works, governance, production, environment and land were the priority areas identified by PRDP upon which all stakeholders would orient their interventions. Considerable emphasis was placed on access to resources of production to create household cash flows to facilitate self-sustenance and wellbeing.

World Bank and European Union were the leading funders of PRDP, either directly through budget support to government, or through off-budget support to CSOs whose interventions were as a requirement aligned to PRDP priorities. It was with support from DFID that CSOs such as VSO were funded to build the capacity of the community, in particular the youth to actively participate in production to improve 
their livelihoods. Indeed, through the DFID support, VSO was able to replicate the skills development programme for the youth, which was implemented by NUSAF I under the youth opportunities programme. It was noted during interview with VSO official (Gulu, July 10, 2015) that VSO scaled-up skills training for the youth in the areas of carpentry, brick laying, tailoring, motor vehicle mechanics, hairdressing, metal fabrication and other mixed skills, in addition to supporting business enterprises for organised youth that benefitted from the training. While the contribution of CSOs is overall commendable, our findings resonate with Bigirimana's observation that "funds through off-Budget support were difficult to quantify as some of the Development Partners who funded this were most of the time cagy about sharing the information" (2015: 64).

Most of the key informants agreed that their organisation's involvement in postconflict northern Uganda was solely prompted by the humanitarianism imperative, with structured development interventions only embraced along the way. Fortunately, there was also agreement that the community and the Government of Uganda received CSOs' involvement in post-conflict northern Uganda with warm welcome and support. This overwhelming appreciation is understood in the context of the shift in focus from humanitarian action to post-conflict reconstruction and development.

There were positive indications of civil society personnel or staff as being very dedicated to carry out the everyday organisation's mandate in post-conflict northern Uganda. Limited financial resources negatively affected the ability of CSOs to impact effectively on their beneficiaries. Whereas transparency increased with accountability among CSOs, there was inexplicable stagnation with regard to discipline in resource management. There was consensus among stakeholders that the principles of impartiality and neutrality were strictly safeguarded and adhered to in the promotion of post-conflict peace and development, as was the case with the principle of do-noharm.

Despite the comprehensive and unified framework of response under PRDP through which interventions of CSOs must be implemented, their organisational interests remain inclined toward institutional survival and retain abundant power over decision-making and distribution of funds. The unified operational framework has not been able to completely out-do the patron-client relationship between CSOs and the beneficiary communities, which still limits the latter's genuine participation in and ownership of the development initiatives. This, inevitably, threatens programme sustainability and empowerment outcomes. For CSOs to reclaim their grassrootscentred approach, participatory design and implementation must be taken more seriously. Without greater commitment to a community-driven and grassroots approach, there is no means through which programmes of CSOs can be realigned with local realities and brought closer to goals of empowerment. Besides, international donors structure their spending to achieve particular goals, which goals may not always easily be aligned with local agenda, which inevitably, limits their impact. 


\section{Conclusion and recommendations}

The role of civil society in post-conflict development of northern Uganda is explored within the framework of the transition from crisis-driven interventions of wartime to the reflective and more comprehensive post-conflict-reconstruction and development. Cognisant of the centrality of peace as a necessary precondition for sustainable development, the analysis has harnessed various feedbacks in terms of attitudes, behaviours as well as interests, which ensued from different interventions by CSOs in post-conflict peace, reconstruction and development of northern Uganda.

There was expressed appreciation of the interventions by CSOs by all key stakeholders, notably the opinion leaders from within the community, especially the grassroots community for whom these interventions were meant. The interventions were initially purposed to alleviate suffering during the turbulent conflict scenario with the change in mindset towards effective reconstruction and sustainable development in post-conflict northern Uganda. However, it should be noted that appreciation of the role of CSOs was in some respects met with mixed feelings. While their interventions remain responsive to the needs and interests of the local community; therefore, largely appreciated by the beneficiaries, the high enthusiasm that characterised the war scenario appeared to dwindle in favour of home grown interventions and active involvement of the local actors.

Civil society organisations played a dominant role in providing relief and livelihoods interventions during war, as the government was largely preoccupied with containing the armed rebellion. However, the government of Uganda through the initiation of PRDP played a central role in providing a comprehensive and overarching framework for post-conflict reconstruction and development of northern Uganda, consistent with Roht-Arriaza's (2010) observation that the national state is the starting place for any discussion in post-conflict reconstruction. It is instructive that the centrality of the state did not compromise the importance of the complementally role of CSOs and the importance of symbiotic relationship between the state and CSOs if the respective efforts were to achieve their intended benefits. The close collaboration between the state and CSOs also brings to light the fact that from policy definition through national identity and resource allocation, other non-state actors also play a formidable role (Bartoli, 2009). To sustain the collaborative efforts between the state and CSOs for sustainable peace and development of northern Uganda, it is critical that actors take note of simmering issues

\section{Re-civilising civil society organisations}

Civil society organisations are largely donor-dependent; hence, they continue to face challenges reconciling donor interests with local needs. To be able to play their increasingly significant role in post-conflict reconstruction and development, CSOs should return to their civil roots, and engender participatory and experimental 
approaches to recovery and development empowerment. To cement their roots and contribute to development, there is need for a shift away from their role as service providers to that of facilitators to enable beneficiary communities to engage actively in the post-conflict development process. Given their closer proximity to the communities, CSOs should provide a more effective framework for building capacity and empowering the people to own and direct the development agenda.

\section{Review of the land question in northern Uganda}

Being at the centre-stage of human development, land remains the most valuable source of livelihoods. Not only does land guarantee human survival after people are born, but it also ensures a decent repository after people are dead. However, as livelihood expression par excellence, the question of land tenure in northern Uganda ought to be reviewed within all parameters of human survival, holistic development and sustainable peace.

In post-war northern Uganda, clashes between customary (clan-owned) land tenure and private (individual-owned) ownership of land are increasing. Yet more intricate, the former system is currently envisaged to be a structurally cultured system, which has been rendered marginal, but not yet superseded. However, the latter system is perceived as the up-to-date system with a blessing of government, although it utterly lacks support from the cultural institution. Worse still, the new generation of campborn people (those born in IDPCs at the time of war who now are adults) have become, within formal legal framework, landless citizens. Meanwhile, a huge portion of the population in northern Uganda, especially in Acholiland, majority of whom are women and their children are structurally marginalised by the existing customary land tenure.

\section{Reassessment of the decentralisation policy}

While decentralisation as a government policy has been implemented for over two decades now, in northern Uganda this remains an on-going experiment. Following the disruption by the war, decentralisation was never a reality in northern Uganda. While in many parts of the country decentralised administrative units are no longer named after identity groups (customary names), northern Uganda is an exception. Its decentralised administrative units are still named after identity groups such as Pajong or Pubec parishes in Mucwini sub-county. Both Pajong and Pubec are examples of current decentralised administrative units (parishes) of a local government entity (Kitgum District) evidently named after Pajong and Pubec clans, respectively. This has undoubtedly contributed to the predicament of harmonious co-living, especially the question of ownership in the aftermath of internal displacements.

Hence, unless the implementation of the decentralisation policy in post-war northern Uganda is revisited in line with the ideals for which state actors and CSOs 
are dedicated, most beneficiaries at the grassroots level may never have an opportunity to influence and own development programmes being implemented; or may equally never be empowered to hold local officials accountable for their actions. With sheer lack of legitimacy and accountability on the part of leadership in such a society emerging from violent conflict, the pursuit of social justice as well as attainment of durable peace and development will undoubtedly remain elusive. Perhaps, the solution to bad governance and poor service delivery is not the proliferation of government to lower levels (decentralised units), because in such circumstances, decentralisation may simply manifest the ripple effects of the central government system (Okidi and Guloba, 2006).

\section{An adequately developed and supported transitional justice policy}

In a country emerging from turbulent times of armed conflict, the need for a national transitional justice policy cannot be overemphasised. Although the twice-amended Amnesty Act enacted by the Uganda Parliament in 2000 vowed to respond to the twodecade long armed conflict, it points to the fact that a much more wide-ranging policy on transitional justice is needed for Uganda as a whole. There is already ample indication that in the absence of a definite policy on transitional justice measures, victims of past abuses will hasten to take matters pertaining to justice in their own hands. Simply put, yesteryear's victims are more likely to become today's perpetrators in the absence of a comprehensive response to address past evils.

Fortunately, CSOs such as Refugee Law Project have worked closely with the Justice, Law and Order Sector (JLOS) to develop the Transitional Justice policy. This policy is conceived as a detailed roadmap charting the trajectory by which the Ugandan society could move from a state of injustice to justice and from oppressive government to a government, which respects human rights and the rule of law. In a special way, the policy is concerned with the administration of justice from within the context of a Ugandan society emerging from turbulent times. As such, apart from being context-specific, the policy also draws its resources (transitional justice mechanisms) from tradition (cultural beliefs and practices) in a forward-looking manner. If well implanted, the policy will provide empirical answers to old questions of transitional justice, in particular assessing the extent, standards, and appropriateness of transitional justice. Effective transitional justice both lays out a strong foundation for and is a major component for post-conflict reconstruction and development.

\section{References}

Abdalla, A., and Attenello, M., 2002. Understanding CR SIPABIO: A conflict analysis model. Say Peace: Conflict Resolution Training Manual for Muslim Communities, pp.44-51 
Angucia, M., 2010. Broken Citizenship; formally abducted children and their reintegration in northern Uganda. Amsterdam: Rozenberg Publishers.

Aptel, C., and Ladisch, V., 2011. Through a new lens: A child-sensitive approach to transitional justice. International Center for Transitional Justice, August 2011. [Online] Available From: www.ictj.org [Accessed 19 July 2016]

Azar, E. E., 1990. The Management of Protracted Social Conflicts: Theory and Cases. Hampshire: Dartmouth Publishing Company Limited.

Bartoli, A., 2009. NGOs and Conflict Resolution. In: The Sage Handbook of Conflict Resolution. Bercovitch, J., Kremenyuk,V., and Zartman, I.W., (Eds)., Los Angeles: SAGE. 392-411, 2009

Bartlet, M., 2009. Forgiveness, Reconciliation and Judicial Process in Northern Uganda: The Lord's Resistance Army and the International Criminal Court. Africa Peace and Conflict Journal, Vol. 2(2): 42-57

Bigirimana, P., 2015. From tears to cheers: A brief analysis of the reconstruction of Northern Uganda (2007-2012). Kampala: Deft Publishing Ltd

Bryman, A., 2008. Social Research Methods, $3^{\text {rd }}$ edition. Oxford: Oxford University Press.

Cohen, J. L., and Arato, A., 1994. Civil Society and Political Theory. Cambridge: MIT Press

Cohen, L., Manion, L., and Morrison, K., 2007. Research Methods in Education, $6^{\text {th }}$ edition. London and New York: Routledge.

Culbertson, H., 2010. The evaluation of peacebuilding initiatives: Putting learning into practice. In: Strategies of Peace: Transforming Conflict in a Violent World. Philpott, D., and Powers, G. F., (Eds.). Oxford: Oxford University Press, 2010, pp. $65-90$

DeWiel, B., 2008. A conceptual history of civil society: From Greek beginnings to the end of Marx. Past Imperfect, 6.

Dicklitch, S., 1998. The elusive promise of NGOs in Africa: Lessons from Uganda. Macmillan: London

Druckman, D., 2005. Doing research: Methods of inquiry for conflict analysis. London: Sage Publications.

Ehrenberg, J., 1999. Civil Society: The critical history of an idea. New York: New York University Press

Ferguson, A., 1995. An essay on the history of Civil Society. New Brunswick, NJ: Transaction Publishers

Gingyera-Pinycwa, A. G., 1992. Northern Uganda in national politics. Kampala: Fountain Publishers.

Huyse, L., 2008. "Introduction: tradition-based approaches in peacemaking, transitional justice and reconciliation policies". In: Traditional Justice and Reconciliation after Violent Conflict: Learning from African Experiences. Huyse, L., and Salter, M., (Eds) Stockholm: International Institute for Democracy and Electoral Assistance, 2008, pp. 1-21. 
Kumar, K., 1994. Civil Society. In: The Blackwell Dictionary of Twentieth-Century Social Thought. Outhwaite, W., and Bottomore, T., (Eds). Paperback edition, Blackwell, Cambridge, Mass, 1994

Latigo, O. J., 2008. "Northern Uganda: tradition-based practices in the Acholi region." In: Traditional Justice and Reconciliation after Violent Conflict: learning from African experiences. Huyse, L., and Salter, M., (Eds). Stockholm: International Institute for Democracy and Electoral Assistance, 2008

Lederach, J. P., 1997. Building peace, sustainable reconciliation in divided societies. Washington DC: United States Institute of Peace Press

McEvoy-Levy, S., 2011. Children, Youth and Peacebuilding. In: Critical Issues in Peace and Conflict Studies; Theory, Practice and Pedagogy. Matyok, T., Senehi, J., and Byrne, S. New York: Lexington Books, 2011, pp. 159-176

Okidi, J. A., and Madina, G., 2006. Decentralisation and Development: Emerging issues from Uganda's experience. Occasional Paper, 93810, Economic Policy Research Centre

Omach, P., 2011. Understanding obstacles to peace in the Great Lakes Region; Actors, interests and strategies. In: Understanding obstacles to peace; Actors, interests and strategies in Africa's Great Lakes Region. Mwesiga, B., (Ed). Fountain Publishers, Kampapa, 2011, pp. 271-306

Oryem, L. C., 2004. Breaking the cycle of violence. Mennonite Central Committee Peace Office Publication, Vol. 34 (2):3-10. [Online] Available From: http://www.mcc.org/respub/pon/pon_04_02.pdf [Accessed 21 July 2017]

OXFAM, 2014. Taking Stock of a Theory of Change; An Assessment of OXFAM's Civil Society Partners' Influencing Role on Land Rights and Gender Issues in northern Uganda, Kampala

Paffenholz, T., 2010. Civil society and peacebuilding: A critical assessment. USA: Lynne Rienner publishers, Boulder, USA

Philpott, D., 2010. Introduction: Searching for strategy in an age of peacebuilding. In: Strategies of peace, transforming conflict in a violent world. Philpott, D., and Powers, G.F., (Eds.). Oxford: Oxford University Press, 2010, pp. 3-18

Republic of Uganda, 2012. Monitoring and Evaluation Framework for PRDP 2, Kampala, Uganda: Office of the Prime Minister, June 2012

Republic of Uganda, 2012. Peace, Recovery and Development Plan, PRDP 2; Grant Guidelines for Local Governments, Kampala, Uganda: Office of the Prime Minister

Roht-Arriaza, N., 2010. Human rights and strategic peacebuilding. In: Strategies of Peace, Transforming Conflict in a Violent World. Philpott, D., and Powers, G.F., (Eds). Oxford: Oxford University Press, 2010, pp. 231-246

Seligman, A., 1992. The idea of Civil Society. New York: Free Press

Starr, F., 1999. Civil Society in Central Asia. In: Civil Society in Central Asia. Holt, R. M., and Waugh, D., (Eds). The Central Asia-Caucasus Institute, in association with University of Washington Press, Washington, 1999 
UNESCO, 2016. UNESCO in brief. [Online] Available From: http://en.unesco.org/about-us/introducing-unesco [Accessed 25 May 2015]

USAID Fact Sheet, 2014. [Online] Available From: file:///C:/Users/Denis/Downloads/USAID_Uganda_Office_of_Democracy_Govern ance_and_Conflict_Fact_Sheet.pdf [Accessed 30 July, 2014]

VSO's, 2012. Uganda Strategy. [Online] Available From: file:///C:/Users/Denis/Downloads/uganda-strategy-2012 [Accessed in 2015]

Woocher, L., 2011. Conflict assessment and intelligence analysis: Commonality, convergence and complementarity. Special Report 275, United States Institute of Peace

\section{Author Biography}

Denis Musinguzi (PhD) is a Governance and Development Senior Lecturer/Researcher in the School of Arts and Social Sciences (SASS), Uganda Martyrs University. He specialises in the areas of human rights, public policy, development policy and strategies, transitional justice and social transformation. He is currently serving as Dean, School of Arts and Social Sciences at Uganda Martyrs University. 